\title{
ANALISIS KEBIJAKAN INISIASI MENYUSU DINI (IMD) DAN PEMBERIAN AIR SUSU IBU EKSLUSIF DI RS BERSALIN BUDI KEMULIAAN JAKARTA
}

\author{
Siti Syamsyiah¹, Hardisman²
}

\begin{abstract}
Abstrak
Rumah Sakit Bersalin (RSB) Budi Kemuliaan Jakarta adalah salah satu RS Sayang Bayi yang menjalankan Inisiasi Menyusu Dini (IMD) sebagai prosedur yang wajib di kerjakan oleh tenaga penolong saat membantu proses persalinan sejak tahun 2008. Tujuan penelitian ini adalah untuk mengetahui bagiamana kebijakan dan implementasi IMD dan advokasi ASI ekslusif di RS Bersalin Budi Kemuliaan. Studi dilakukan secara kualitatif berdasarkan analisis dokumendokumen terkait dan observasi langsung ke lapangan pada trimester terakhir tahun 2013 (Oktober-Desember 2013). Hasil kajian ini memperlihatkan pelaksanaan IMD dan pemberian ASI ekslusif di RS Bersalin Budi Kemuliaan belum optimal karena kurangnya fasilitas pendukung, kejelasan implementasi kebijakan dan advokasi petugas kesehatan. Studi ini menunjukkan bahwa IMD dan ASI ekslusif sangat ditentukan oleh advokasi yang baik dan petunjuk teknis kebijakan yang jelas. Studi ini juga memperlihatkan bahwa kesuksesan pencapaian ASI eksklusif terkait dengan keberhasilan pencapaian IMD
\end{abstract}

Kata kunci: ASI ekslusif, IMD, Kebijakan

\begin{abstract}
Maternity Hospital (RSB) Budi Kemuliaan Jakarta has implemented friendly hospital Early Initiation of Breastfeeding (EIB) approach as standard procedure for asssisting childbirth process since 2008. This study was carried out to examine the policy and the implementation of EIB and exclusive breastfeeding policy in the Maternity Hospital Budi Kemuliaan. To answer the research objectives, the qualitative study was conducted using document analysis and direct observation from Oktober to Desember 2013. The result of the study revealed that the implementation of EIB and the implementation of exclusive breastfeeding did not reach the target due to lack of supporting factors, advocacy, and clear guideline of the policy. The study also indicated that successful implementation exclusive breasfeeding policy related to successful of EIB.
\end{abstract}

Keywords: Exclusive Breastfeeding, EIB, Policy

Affiliasi Penulis : 1. Sekolah Tinggi IImu Kesehatan Indonesia Maju (STIKIM), Jakarta. 2. Fakultas Kedokteran Universitas Andalas (FK-Unand), Padang. Korespondensi: hardisman, Fakultas Kedokteran Universitas Andalas, Jl. Perintis Kemerdekaan No.94 Padang, email: hardisman@fk.unand.ac.id 


\section{PENDAHULUAN}

Berbagai penelitian telah mengkaji menfaat pemberian Air Susu lbu (ASI) ekslusif dalam hal menurunkan mortabilitas bayi, morbiditas bayi, mengoptimalkan pertumbuhan bayi, membantu perkembangan kecerdasan anak dan membantu memperpanjang jarak kehamilan bagi ibu. ${ }^{1,2} \mathrm{Di}$ Indonesia, Departemen Kesehatan Republik Indonesia melalui program perbaikan gizi, masyarakat telah menargetkan cakupan Air Susu Ibu ekslusif 6 bulan sebesar $80 \%$. Namun demikian angka ini sangat sulit untuk di capai bahkan tren prevalensi Air Susu lbu ekslusif dari tahun ke tahun terus menurun. Data Survei Demografi dan Kesehatan Indonesia 1997-2007 memperlihatkan terjadinya penurunan prevalensi Air Susu Ibu ekslusif dari 40,2\% pada tahun 1997 menjadi $39,5 \%$ dan $32 \%$ pada tahun 2003 dan 2007.3.4

Melalui Millenium Development Goads (MDGs) atau tujuan pem-bangunan millennium adalah sebuah paradigma pembangunan global, di deklarasikan pada konferensi Tingkat Tinggi Millenium oleh 189 negara anggota Perserikatan bangsa - bangsa (PBB) di New York pada bulan September 2000. Tujuan MDGs yang keempat adalah menurunkan angka kematian bayi dan balita menjadi $2 / 3$ dalam kurun waktu 1990-2015. ${ }^{5}$ Penyebab utama kematian bayi dan balita adalah diare dan pneumonia dan lebih dari $50 \%$ kematian balita didasari oleh kurang gizi. Pemberian ASI secara ekslusif selama 6 bulan dan di teruskan sampai usia 2 tahun di samping pemberian makanan pendamping ASI (MP ASI) secara adekuat terbukti merupakan salah satu inter- vensi efektif dalam menurunkan Angka Kematian Bayi (AKB). ${ }^{5}$ Sedangkan tujuan MDGs yang kelima adalah peningkatan kesehatan ibu dengan target menurunkan angka kematian ibu sebesar $3 / 4$ sampai tahun 2015. Menyusui berakibat dengan penurunan resiko perdarahan saat persalinan, kanker payudara, kanker ovarium dan kanker endometriosis. Selain itu dengan pemberian ASI ekslusif dapat menjadi alat kontrasepsi yang baik dan dapat menurunkan kehamilan. ${ }^{5}$

Alasan yang menjadi penyebab kegagalan praktek Air Susu Ibu ekslusif bermacam-macam seperti misalnya budaya memberikan makanan pralaktal, memberikan tambahan susu formula karena Air Susu ibu tidak keluar, menghentikan pemberian Air Susu Ibu karena bayi atau ibu sakit, ibu harus bekerja, serta ibu ingin mencoba susu formula. Studi kualitatif fikawati dan Syafiq melaporkan factor predisposisi kegagalan Air Susu Ibu ekslusif adalah karena faktor predisposisi yaitu pengetahuan dan pengalaman ibu yang kurang dan factor pemungkin penting yang menyebabkan terjadinya kegagalan adalah karena ibu tidak di fasilitasi melakukan Inisiasi Menyusui Dini (IMD). ${ }^{6}$

Bayi yang lahir normal dan diletakkan di perut ibu segera setelah lahir dengan kulit ibu melekat pada kulit bayi selama setidaknya 1 jam dalam 50 menit akan berhasil menyusui, sedangkan bayi lahir normal yang dipisahkan dari ibu nya $50 \%$ tidak bias menyusu sendiri. ${ }^{7}$ Berbagai studi juga telah melaporkan bahwa Inisiasi Menyusu Dini terbukti meningkatkan keberhasilan Air Susu Ibu ekslusif. ${ }^{7,8}$ Inisiasi Menyusu Dini dengan jelas telah tercantum dalam Buku Acuan Asuhan Persalinan (APN) 
dari Departemen Kesehatan Republik Indonesia. ${ }^{9}$ Asuhan persalinan normal (APN)adalah standar asuhan persalinan normal yang bersih dan aman dari setiap thapan persalinan bagi semua ibu bersalin yang harus di terapkan oleh penolong persalinan dimanapun hal tersebut terjadi.

Rumah Sakit Ibu dan Anak (RSIA)

Budi Kemuliaan Jakarta adalah salah satu RS Sayang Bayi yang menjalankan IMD sebagai prosedur yang wajib di kerjakan oleh tenaga penolong saat membantu proses persalinan sejak tahun 2008. Berdasarkan Survey awal jumlah persalinan di RSIA Budi Kemuliaan relatif tinggi yaitu tahun 2009 sebesar 7977 persalinan, tahun 2010 sebesar7773 persalinan dan tahun 2011 sebesar 7948 persalinan. Dari jumlah tersebut sebanyak $80 \%$ di tolong oleh tenaga bidan dan sisanya sebanyak $20 \%$ ditolong oleh dokter. Salah satu kunci keberhasilan program IMD di RS Budi Kemuliaan tergantung pada kualitas kinerja bidan.

Tujuan Asuhan Persalinan Normal adalah untuk menjaga kelangsungan hidup dan derajat kesehatan yang tinggi bagi ibu dan bayi yang dilahirkannya. ${ }^{9}$ Penolong persalinan disini mungkin saja seorang bidan, perawat, dokter umum atau spesialis obstetri. Karena bidan secara umum merupakan penolong persalinan yang paling banyak membantu persalinan ibu di. ${ }^{3,4}$

Studi kualitatif pada ibu-ibu di wilayah Puskesmas Kecamatan Jagakarsa Jakarta Selatan melaporkan bahwa IMD berpengaruh nyata terhadap pelaksanaan Air Susu Ibu ekslusif. Peran tenaga kesehatan sebagai penolong persalinan dalam IMD adalah vital, dan Ibu-lbu yang difasilitasi dalam IMD lebih cendrung untuk memberikan ASI ekslusif ${ }^{6}$ Oleh karena itu, penelitian ini dilakukan untuk menganalisis implementtasi dan kebijakan IMD di RS Bersalin Budi Kemuliaan sebagai upaya untuk membantu meningkatkan pencapaian target $\mathrm{ASI}$ ekslusif.

\section{METODE}

Kajian Implementasi Air Susu Ibu (ASI) ekslusif dan Inisiasi Menyusu Dini (IMD) disajikan secara deskriptif berdasarkan studi-studi yang ada sedangkan analisis kebijakan di lakukan dengan menggunakan pendekatan Walt et al dan kerangka kerja koalisi advokasi Weible \& Sabatier.10,11 Analisis untuk studi kebijakan dilakukan berdasarkan model analisis kebijakan yang terdiri atas aspek konten, konteks, proses dan aktor leh Wal et al. ${ }^{10}$ Sedangkan untuk melakukan kritis terhadap kebijakan tersebut digunakan sejumlah pertanyaan yang relevan berdasarkan teori Palmer \& Short. ${ }^{12}$. Dalam kajian ini, kedua pendekatan tersebut di gabungkan dan kemudian di tinjau sekali lagi dengan kerangka koalisi advokasi sebagai bentuk trianglasi metode analisis.

Studi implementasi IMD dan pemberian ASI eksklusif di RS Budi Kemu-iaan Jakarta dilakukan degan pendekatan kualitatif. Data-data didapatkan dengan telaah dokumen-dokumen kebijakan terkait dan melakukan observasi langsung pada trimester terakhir tahun 2013 (Oktober-Desember 2013).

\section{HASIL DAN PEMBAHASAN}

\section{Kajian Implementasi ASI Ekslusif}

Sebelum tahun 2001, World Health Organization (WHO) merekomendasikan untuk memberikkan ASI ekslusif 
selama 4-6 bulan. Namun pada tahun 2001, setelah melakukan telaah artikel penelitian secara sistemik dan berkonsultasi dengan para pakar, WHO merevisi rekomendasi ASI ekslusif tersebut dari 4-6 bulan menjadi 6 bulan. ${ }^{13}$

Pola pemberian makan terkait untuk bayi sejak lahir sampai anak berumur 2 tahun meliputi (a) memberikan ASI kepada bayi segera dalam waktu 1 jam setelah lahir,(b) memberikan hanya ASI saja sejak lahir sampai 6 bulan.Hampir semua itu dapat dengan sukses menyusui di ukur dari permulaan pemberian ASI dalam jam pertama kehidupan bayi.Hasil telaah artikel tersebut menyimpulkan bahwa bayi yang disusui secara ekslusif sampai 6 bulan umumnya lebih sedikit menderita penyakit gastrointestinal dan lebih sedikit mengalami gangguan pertumbuhan. ${ }^{13,14}$ Dalam upaya mencerdaskan kehidupan bangsa, maka harus dilahirkan generasi penerus bangsa yang cerdas, sehat jasmani dan rohani. Untuk itu perlu penciptaan kondisi yang mendukung ke arah tersebut, di antaranya dengan pemberian Air Susu Ibu (ASI) secara ekslusif 6 bulan dan di lanjutkan pemberian ASI sampai anak berusia 2 tahun. ${ }^{4}$

Penerapan ASI ekslusif 6 bulan harus didukung oleh berbagai kebijakan seperti cuti untuk ibu menyusui, undangundang pemasaran susu formula, sanksi untuk iklan susu formula, sanksi untuk bidan yang memberikan dan mengenalkan susu formula kepada bayi dan peningkatan kualitas ante-natal-care. Pengamatan kualitatif perhadap pemberian ASI ekslusif oleh ibu-ibu yang bersalin dan melakukan perawatan bayi di RS Budi kemuliaan menunjukkan rendahnya penerapannya dan kurangnya antusias ibu untuk melakukannya.

Penelitian di wilayah Jakarta utara oleh Mercy Corps secara kuantitatif juga menunjukkan rendahnya prevalensi ASI ekslusif. ${ }^{15}$ Laporan studi tersebut memperlihatakan walaupun definisi ASI esklusif yang di gunakan berbeda-beda, ada definisi yang ketat dan ada pula yang longgar, namun cakupan ASI ekslusif yang di dapatkan tidak pernah tinggi. Sama halnya dengan prevalensi ASI ekslusif menurut data SDKI hanya $32 \%,{ }^{4}$ pada penelitian Mercy Corps juga didapatkan sangat kecil yaitu sebesar $7,4 \%$ (ASI predominan pada bayi usia 05 bulan) dan 28,9\% (ASI saja dalam dalam 24 jam terakhir pada bayi usia 0-5 bulan). ${ }^{15}$

Begitu juga halnya survey yang dilakukan oleh Helen Keller Internasional menyebutkan bahwa rata-rata bayi di Indonesia hanya mendapatkan ASI ekslusif selama 1,7 bulan. ${ }^{16}$ Target pencapaian ASI ekslusif 6 bulan sebesar 80\% yang ditetapkan Depkes RI tampak terlalu tinggi. Oleh karena itu, WHO merekomendasikan untuk memberikan hanya Air susu lbu (ASI) saja sampai 6 bulan untuk keuntungan yang optimal bagi ibu dan bayi. ${ }^{13}$

Dari data-data tersebut terdapat beberapa rekomendasi terkait pemberian ASI ekslusif. Pertama rekomendasi ini bisa di capai bila masalah-masalah potensial seperti status gizi ibu hamil dan laktasi, status mikronutrien (zat besi, seng dan vitamin A) bayi dan pelayanan kesehatan dasar rutin bagi bayi (pengukuran pertumbuhan dan tanda klinis defisiensi mikronutrien) sudah berhasil di atasi. Bila hal ini belum tercapai maka mungkin akan timbul masalah seperti terjadinya growth 
faltering pada bayi ibu laktasi yang memaksakan memberikan ASI ekslusif selama 6 bulan kepada bayinya.

Kedua, perlunya pemberian makanan pendamping ASI yang tepat dan memperkenalkan makanan bergizi yang adekuat dan aman dalam hubungannya dengan pemberian ASI selanjutnya.Dalam hal ini perlu dikaji makanan pendamping ASI yang tepat termasuk sesuai kondisi gizi dan umur bayi. Rata-rata pemberian ASI ekslusif di Indonesia hanya 1,7 bulan, sedangkan di RS Bersalin Budi Kemuliaan sendiri sejak lahir sampai 1 tahun minimal, maka perlu di berikan petunjuk yang jelas mengenai makanan pendamping apa saja yang dapat diberikan. Ketiga, kondisi yang dibutuhkan untuk menerapkan kebijakan ini adalah pemberian dukungan social dan gizi yang adekuat untuk ibu yang sedang menyusui.

\section{Kajian Implementasi IMD}

Pengetahuan dan pemahaman akan pentingnya IMD pada bayi baru lahir menjadi suatu kebutuhan bagi semua petugas kesehatan dan masyarakat luas terutama ibu - ibu yang sedang hamil. Rendahnya cakupan ASI Ekslusif di RS Bersalin Budi Kemuliaan dipengaruhi oleh rendahnya informasi dan edukasi pelaksanaan IMD kepada masyarakat oleh petugas kesehatan. Selain itu persepsi dan pendapat masyarakat yang kurang paham tentang IMD juga menjadi penghambat.

Bidan merupakan tenaga kesehatan yang paling berperan dalam melaksanakan IMD karena ibu tidak dapat melakukan IMD tanpa bantuan dan fasilitas dari bidan. Penelitian kualitatif ASI ekslusif 6 bulan terhadap kelompok ibu yang ASI ekslusif dan ASI tidak ekslusif menunjukkan bahwa sebagian besar informan ASI ekslusif difasilitasi IMD oleh bidan sedangkan sebagian besar informan ASI tidak ekslusif tidak di fasilitasi IMD. ${ }^{6}$

Tenaga kesehatan dan penyelenggara fasilitas pelayanan kesehatan wajib melakukan IMD terhadap bayi yang baru lahir kepada ibunya paling singkat selama 1 jam. IMD di lakukan dengan cara meletakkan bayi secara tengkurap di dada/perut ibu sehingga kulit bayi melekat pada kulit ibu. IMD dilakukan dalam keadaan ibu dan bayi stabil dan tidak membutuhkan tindakan medis selama paling singkat 1 jam. Lama waktu IMD selama 1 jam di maksudkan untuk memberikan kesempatan kepada bayi agar dapat mencari putting susu ibu dan menyusu sendiri.

Edmond dkk ${ }^{1}$, menyebutkan bahwa menunda inisiasi menyusu dini akan meningkatkan kematian bayi. Penelitian nya melaporkan bahwa dari 10.947 bayi yang lahir antara Juli 2003Juni 2004 dan disusui, menyusu dalam 1 jam pertama akan menurunkan angka kematian perinatal sebesar $22 \%$ dan kemungkinan kematian meningkat secara bermakna setiap hari permulaan menyusu di tangguhkan.

Penelitian Anita, di salah satu rumah sakit pusat rujukan di Jakarta Pusat menunjukkan hubungan yang signifikan antara bidan yang mempunyai sikap positif terhadap IMD dengan penerapan praktik IMD.20 Artinya bidan yang bersikap positif akan lebih besar kemungkinannya untuk melakukan IMD. Sikap positif bidan terhadap IMD antara lain adalah bidan merasa senang bila ibu mengerti akan pentingnya IMD, bidan mau menyebarluaskan informasi tentang pentingnya IMD, bidan mau membantu 
melaksanakan IMD dan bidan tidak mau memberikan susu botol kepada bayi.

Studi kualitatif di salah satu Puskesmas di Kabupaten Solok Sumatera Barat terhadap bidan dan ibu bersalin juga menunjukkan kurangnya fasilitasi dan kualitas IMD yang dilakukan oleh bidan. ${ }^{17}$ Dalam studi tersebut bidan mengakui dalam IMD tidak terjadi kontak kulit antara ibu dan bayi karena bayi di berikan ke ibu dalam keadaan sudah terbungkus dan mereka umumnya pernah memberikan susu bantu kepada bayi dengan indikasi bila dalam 2 jam ASI belum keluar. Hal ini tentunya sangat tidak sesuai dengan prosedur APN yang di tetapkan. ${ }^{9}$

Berdasarkan monitoring yang dilakukan oleh BPKK-ASI disebutkan bahwa banyak rumah sakit bersalin yang tidak mendukungIMD. ${ }^{16}$ Sehabis dilahirkan bayi seharusnya langsung diletakkan di dada ibu agar refleksnya berkembang dan produksi ASI ibu meningkat namun bayi malah dipisahkan dan baru diberikan sehari kemudian. Roesli, melakukan penyuluhan di berbagai daerah di Indonesia sebagai upaya menggerakan kesadaran bidan untuk mau memfasilitasi ibu bersalin melakukan IMD. ${ }^{18}$

Ada beberapa alasan bagaimana pentingnya kontak dengan kulit setelah lahir dan menyusui dalam 1 jam pertama kehidupan antara lain:

1. Tubuh ibu membantu menyimpan kehangatan yang tepat,terutama penting pada bayi kecil dan BBLR (Berat Badan Lahir Rendah).

2. Mengurangi stress pada bayi, pernafasan dan detik jantung bayi lebih stabil dan bayi lebih jarang menangis.
3. Saat merangkak mencari payudara ibu, bayi-bayi memindahkan bakteri dari kulit ibu nya dan ia akan menjilat kulit ibu dan menelan bakteri di kulit ibu.

4. Bayi menerima kolostrum/ cairan emas sebagai makanan pertama yang mengandung banyak zat gizi untuk antibody dan kekebalan tubuh serta mempercepat pengeluaran meconium pada bayi.

5. Hisapan bayi pada ibu akan merangsang pengeluaran hormon oksitosin.

6. Terbentuk bonding antara ibu dan bayi.

\section{Analisis Kebijakan}

Sampai saat ini terdapat beberapa legislasi terkait dengan pemberian ASI ekslusif di Indonesia yaitu Peraturan Menteri Kesehatan. 240/MENKES/PER/$\mathrm{V} / 1985$ tentang pengganti ASI. ${ }^{19}$ Keputusan Menteri Kesehatan RI No.237/Menkes/SK/IV-/1997 tentang pemasaran pengganti ASI. ${ }^{20}$ Peraturan Pemerintah No.69 tahun 1999 tentang Label dan Iklan Pangan. ${ }^{21}$ dan Kepmenkes RI No.450/Menkes/SK/IV/2004 tentang Pemberian ASI secara Ekslusif pada Bayi di Indonesia. ${ }^{22}$ Legislasi ini menjadi dasar penerapan kebijakan dan program ASI eksklusif di Indonesia.

\section{Kebijakan World Alliance of Breastfeeding Action (WABA)}

IMD dalam 1 jam setelah kelahiran merupakan tahap penting untuk mengurangi kematian bayi dan mengurangi banyak kematian neonatal. Menyelamatkan 1 juta bayi di mulai dengan 1 tindakan satu persatu dan satu dukungan untuk dimulai IMD dalam 1 
jam pertama kelahiran. WHO/UNICEF merekomendasikan bahwa IMD dalam 1 jam pertama kelahiran, menyusu secara ekslusif selama 6 bulan di teruskan dengan makanan pendamping ASI selama 2 tahun.

Dalam rangka melindungi, mendukung dan mempromosikan pemberian ASI ekslusif perlu di lakukan upaya untuk meningkatkan dukungan dari pemerintah, pemerintah daerah, fasilitas pelayanan kesehatan dan tenaga kesehatan, masyarakat serta keluarga agar ibu dapat memberikan ASI ekslusif kepada bayi. Untuk maksud tersebut, maka diperlukan PP tentang pemberian ASI ekslusif. Dalam PP tersebut di atur tanggung jawab pemerintah, pemerintah daerah provinsi dan pemerintah daerah kabupaten/kota, ASI ekslusif, penggunaan susu formula dan produk bayi lainnya, tempat kerja dan tempat sarana umur, dukungan masyarakat, pendanaan, pembinaan dan pengawasan.

Kompresi tentang hak anak mengakui bahwa setiap anak berhak untuk hidup dan baertahan untuk melangsungkan hidup dan berkembang setelah persalinan. Wanita mempunyai hak untuk mengetahui dan menerima dukungan yang diperlukan untuk melakukan IMD yang sesuai.

Satu legislasi, yaitu Rancangan Peraturan Pemerintah (RPP) Pemberian ASI yang sudah di mulai pembahasan nya sejak November 2006 (saat itu bernama RPP Pemasaran Susu Formula) masih juga belum tuntas di bahsa dan belum bias di luncurkan sebagai Peraturan Pemerintah. ${ }^{23}$ Dalam studi ini, kajian analisis akan dilakukan terhadap Kepmenkes No.450/2004, sedangkan Permenkes No.240/1985 dan RPP Pemberian ASI tidak di bahas karena kedua peraturan tersebut tidak atau belum di aplikasikan.

\section{Analisis Konten}

Kepmenkes No.237/1997 mengenai Pemasaran Pengganti ASI adalah keputusan yang sangat ringkas karena hanya terdiri atas dua buah dan tiga pasal bab pertama berisi mengenai ketentuan umum dan bab kedua mengenai peredaran. Dalam ketentuan Umum di jelaskan definisi umum dan peristilahan yang dipakai dalam Kepmenkes tersebut mencakup istilah pengganti air susu ibu, makanan pendamping ASI, susu formula bayi, susu formula lanjutan, bayi, botol, dot, pemasaran dan promosi. Pengganti ASI hanya dapat diedarkan setelah mendapatkan persetujuan dari Ditjen POM Depkes RI. ${ }^{20}$

Peraturan Pemerintah No.69/1999 tentang label dan Iklan Pangan adalah legislasi yang paling kuat di banding yang lain dan juga paling lengkap karena sudah ada pembagian kewenangan/ tugas meskipun masih perlu di elaborasi dan ditindak lanjuti dengan keputusankeputusan dibawahnya yang mengatur aspek teknis. Dari segi konten PP ini terdiri dari 8 bab dan 64 pasal. Bab pertama membahas mengenai ketentuan umum, bab kedua mengenai label pangan, bab ketiga mengenai iklan pangan, bab ke empat mengenai pengawasan, bab lima mengenai tindakan administrative, bab enam mengenai ketentuan khiusus dan bab delapan adalah ketentuan penutup. ${ }^{21}$

Secara umum, PP tersebut mengatur mengenai pelabelan dan iklan makanan dan minuman secara keseluruhan. Aspek terkait ASI terutama secara eksplisit di sebutkan pada Bab III Pasal 47 Ayat 4 yaitu mengatur 
mengenai pelarangan iklan pangan bagi bayi kurang dari satu tahun di media masa kecuali media cetak khusus kesehatan setelah mendapat persetujuan Menkes, Iklan tersebut juga mewajibkan pencantuman peringatan bahwa makanan tersebut bukanlah pengganti ASI.

Kepmenkes No.450/2004 tentang Pemberian ASI Secara Ekslusif pada bayi di Indonesia terdiri atas lima ketetapan termasuk penetapan mengenai pemberian ASI ekslusif selama 6 bulan dan di lanjutkan sampai dengan usia anak 2 tahun dengan pemberian makanan tambahan yang sesuai. Pemberian informasi dianjurkan untuk mengacu pada 10 Langkah Menuju Keberhasilan Menyusui (LMKM). ${ }^{22}$

Jika di tinjau dari peraturan yang memuat mengenai definisi peristilahan tampak bahwa definisi yang di pakai merujuk pada definisi yang di gunakan atau berlaku pada saat keputusan tersebut di buat. Dalam hal ini, perlu di pertimbangkan bahwa telah terjadi perubahan-perubahan yang cukup cepat dalam hal pengertian dan peristilahan. Misalnya saja, definisi ASI ekslusif pada Kepmenkes No.237/1997 masih merujuk pada durasi pemberian ASI saja selama 4 bulan. Padahal sejak tahun 2002 WHO telah merekomendasikan durasi optimal ASI ekslusif selama 6 bulan. Terlepas dari apakah ada bukti yang cukup kuat untuk mengadopsi rekomendasi WHO tersebut, tetapi updating terhadap situasi keilmuan dan bukti di lapangan tetap harus di lakukan.

Perkembangan terakhir juga belum di akomodasi, misalnya mengenai IMD. Dalam 10 LMKM, pengertian IMD (yang juga belum disebut secara eksplisit sebagai IMD) lebih merujuk pada pemberian ASI segera dalam 30 menit selah melahirkan.

Dari segi kelengkapan, di antara ketiga peraturan tersebut, yang paling komprehensif adalah PP No.69/1999 mengenai Label dan Iklan Pangan. Hal ini dapat disebabkan karena tingkat legislasinya yang lebih tinggi di bandingkan dua peraturan lainnya yang hanya setingkat keputusan menteri. Namun masalahnya PP tersebut bukan PP yang khusus mengenai ASI ekslusif dan IMD, tetapi PP yang mengatur mengenai makanan secara keseluruhan dan pengaturan pelabelan dan iklannya. Perlu di catat bahwa Kepmenkes No.237/1997 dan Kepmenkes No.450/2004 keduanya sangat ringkas dan kurang lengkap sehingga masih perlu ditindak lanjuti dengan aturanaturan teknis yang dalam kenyataannya tidak terdokumentasi dengan baik. Berbeda dengan PP, kedua Kepmenkes tersebut, tidak memuat pendelegasian penugasan dan wewenang kepada implementer serta tidak di lengkapi dengan sanksi baik administratif, perdata, maupun pidana bagi pelanggar keputusan tersebut.

Sampai sejauh ini, aspek evaluasi dan pemantauan terhadap pelaksanaan peraturan-peraturan tersebut belum tersedia informasinya. Hal ini dapat disebabkan oleh buruknya system pendokumentasian dan diseminasinya bagi publik atau karena memang suatu sistem evaluasi dan pemantauan tidak ada dalam system yang di maksud dalam peraturan. Hal ini merupakan kondisi yang mengkhawatirkan karena dalam setiap implementasi kebijakan, harus selalu ada tahap evaluasi implementasi kebijakan tersebut. ${ }^{11,12}$ 
Sedangkan pada RS Bersalin Budi Kemuliaan konten ini diadopsi full oleh system dan SOP yang sdh berlangsung di RS Bersalin Budi Kemuliaan itu sendiri.

\section{Analisis Konteks}

Ditinjau dari segi konteks, tampaknya peraturan-peraturan yang di bahas dalam analisis ini masih terlepas dari konteknya baik konteks individu, keluarga, masyatakat, maupun institusi. Dalam pelaksanaan di lapangan, faktor konteks atau lingkungan memainkan peran yang sangat penting dan menentukan keberhasilan pelaksanaan ASI ekslusif. Studi-studi menunjukkan bahwa di samping faktor internal ibu, situasi dan kondisi lingkungan eksternal juga penting sebagai penentu keberhasilan pelaksanaan IMD dan ASI ekslusif. 5,6

Dalam hal ini perlu diperhatikan pergeseran-pergeseran yang terjadi pada ranah demografi dan sosial ekonomi. Pemberian ASI ekslusif bagi ibu pekerja, misalnya belum diakomodasi oleh peraturan yang ada. Padahal tingkat partisipasi angkatan kerja perempuan meningkat terus presentasinya dari 48,63\% di tahun 2006 menjadi $49,52 \%$ di tahun 2007 dan 51,25\% di tahun 2008. ${ }^{24}$ Dari segi peraturan ketenaga kerjaan (undang-Undang Ketenaga Kerjaan No.13/2003 Pasal 81). ${ }^{25}$ Lama cuti hamil dan melahirkan hanya 3 bulan, ini tentu tidak cukup bagi pelaksanaan ASI ekslusif 6 bulan kecuali jika di fasilitasi dengan instrument penyimpan ASI baik di rumah maupun di tempat kerja.

Situasi sosial-ekonomi masyarakat juga penting mendapatkan perhatian. Terutama yang harus dicermati fenomena pergeseran norma sosial dan kultural terkait pemberian ASI ekslusif, fenomena masifikasi dan kesetaraan pendidikan tinggi dan variasi serta jurang sosia-ekonomi pada berbagai kelompok masyarakat baik di wilayah urban maupun pedesaan. Gencarnya pemasaran susu formula melalui kampanye terselubung, yaitu sebagai hadiah kepulangan ibu dan bayi dari fasilitas persalinan dilaporkan masih marak terjadi. $^{1,6}$ Lebih lanjut, studi kualitatif tentang praktik keberhasilan dan kegagalan ASI ekslusif di Jakarta tahun 2009 menunjukkan bahwa yang sering menjadi korban dari kampanye demikian adalah ibu-ibu berpendidikan rendah. ${ }^{6}$

Kesiapan sarana pelayanan kesehatan khususnya pelayanan kehamilan dan persalinan, termasuk kesiapan SDM nya perlu di perhatikan juga apakah peraturan-peraturan tersebut sudah menyentuh peran dan mempertimbangkan situasinya. Jumlah rumah sakit sayang bagi diperkirakan hanya sekitar $50-70 \%$ pada rumah sakit pemerintah dan $10-20 \%$ pada rumah sakit swasta. ${ }^{23}$ Pelaksanaan IMD dan ASI ekslusif sangat bergantung pada tindakan yang diambil oleh tenaga kesehatan dan fasilitas layanan kesehatan pada jamjam pertama. Berbagai studi menunjukkan peran vital tenaga kesehatan penolong persalinan dalam keberhasilan pelaksanaan IMD dan ASI ekslusif. 5,6,8 Dalam kenyataannya, tidak semua tenaga kesehatan penolong persalinan baik bidan maupun dokter bebas dari peran sebagai "agen" susu formula.

Mengenai hambatan dan kendala pelaksanaan ASI ekslusif 6 bulan sebenarnya sudah mulai banyak muncul pada dekade terakhir ini. Tetapi apakah yang ada juga di jadikan bahan 
pertimbangan dalam mengadopsi kebijakan yang bermula dari studi WHO tersebut?

pertanyaan-pertanyaan mengenai kesesuaian konteks eksternal seperti telah di ulas sebelumnya perlu di jawab dan dicarikan penyesuaianpenyesuaian. Demikian juga perlu kiranya diluncurkan studi yang mengkaji kesesuaian rekomendasi WHO dengan realita situasi antropometri dan fisiologis ibu hamil di Indonesia dengan prevalensi kurang energi kronis pada ibu hamil yang tinggi yaitu masih sekitar $20 \% .^{24}$ Terdapat kemungkinan munculnya akibat gizi yang merugikan baik bagi ibu maupun bayi jika dalam kondisi kekurangan gizi dipaksakan melaksanakan ASI ekslusif selama 6 bulan.

Diperlukan studi yang komprehensif untuk mengkaji situasi ini dan menguji pertanyaan-pertanyaan realita kontekstual seputar ASI ekslusif. Kebijakan selanjutnya, disusun berdasarkan bukti-bukti empirik dan saintifik yang kuat sehingga tidak menyebabkan kebijakan menjadi tidak realistis saat diterjemahkan menjadi program atau malah menimbulkan dampak negatif yang merugikan masyarakat.

Sedangkan Di RS Bersalin Budi Kemuliaan semua kebijakan-kebijakan dan pertanyaan-pertanyaan semua sudah disesuaikan pada peraturan kebijakan yang sudah berlaku di RS Bersalin Budi Kemuliaan sendiri.

\section{Analisis Proses}

Proses penyusunan kebijakan di Indonesia melibatkan setidaknya dua pihak, yaitu pihak eksekutif dan pihak legislative. Pada eksekutif di wakili oleh kementrian teknis yang bersangkutan sedangkan pihak legislative adalah DPRRI. Proses penyusunan legislasi tidak selalu dibuka untuk publik sehingga prinsip transparansi tidaklah selalu dapat dipatuhi. Demikian juga dengan pendokumentasian yang tidak dibuka untuk publik. Kalaupun ada, prosesnya tidak tersosialisasi dengan baik. Dalam hal ini, peran media, pers dan jurnalistik menjadi sangat penting untuk dapat menyampaikan informasi mengenai proses penyusunan suatu kebijakan.

Di samping transparansi, hal lain yang tak kalah penting dalam penyusunan kebijakan adalah pendekatan yang di gunakan apakah partisipasif secara inklusif dengan melibatkan pihak-pihak yang berkepentingan (termasuk rakyat atau dalam hal ini ibu hamil dan menyusui), atau apakah non partisipatif dan ekslusif. Dalam banyak penyusunan kebijakan, sering di kritik bahwa pemerintah dan DPR tidak partisipatif, misalnya proses penyusunan RUU Narkotika yang di kritik keras oleh Indonesian Coalitian for Drug Policy Reform karena tidak melibatkan komunitas pengguna NAPZA. ${ }^{26}$ Terkait dengan sisi partisipasi ini, penting kiranya melibatkan pihak akademisi dan ilmuwan yang obyektif dan netral serta tidak berafilasi pada kepentingan politik tertentu (termasuk pemerintah dan DPR) untuk menyajikan informasi dan data mutakhir secara ilmiah.

Disisi lain, meskipun bersifat partisipatoris, tidak berarti kemudian penyusunan kebijakan harus berjalan lamban. Proses penyusunan kebijakan di bidang ASI yang terakhir, yaitu RPP Pemberian ASI (semula RPP Pemasaran Susu Formula) berjalan sangat lambat dan tersendat. Pembahasan dimulai sejak pertengahan November 2006 dan sampai Januari 2010 belum juga selesai. ${ }^{27,28}$ 
Di RS Bersalin Budi Kemuliaan proses penyusunan kebijakan melibatkan seluruh direksi-direksi serta para tenaga bidan yang senior. Pelaksanaan ASI ekslusif (ASI) dan Inisiasi Menyusu Dini (IMD) berjalan lancar sejak anak lahir 1 jam pertama sampai 2 tahun.Dan para tenaga kesehatan seperti perawat dan bidan sangat mendukung dan membimbing para ibu yang sudah partus untuk segera melakukan Inisiasi Menyusu Dini (IMD) dan ASI ekslusif.

\section{Analisis Aktor}

Aspek partisipatoris dari proses penyusunan kebijakan terkait juga dengan aspek aktor atau pameran yang mentukan dalam implementasi kebijakan tersebut. Idealnya setiap aktor yang terlibat harus jelas posisi dan perannya, kewenangan dan tanggung jawabnya, sehingga tidak terjadi tumpang tindih peran atau malah kevakuman peran. Pemetaan aktor yang terlibat mulai dari penyusunan sampai implementasi dan evaluasi harus jelas tercakup dalam suatu kebijakan atau peraturanperaturan yang menindak lanjutinya serta sesuai secara horizontal (lintas sektoral) maupun vertikal (lintas level).

Pemetaan aktor lebih luas lagi juga mencakup pertimbangan dan tinjauan terhadap kemungkinan keberhasilan dan kegagalan implementasi kebijakan tersebut. Misalnya, dalam hal PP Pemberian ASI, perlu dianalisis reaksi yang akan dimunculkan oleh pihak industry susu formula serta kemungkinan kondisi dilematis yang dihadapi oleh tenaga kesehatan penolong persalinan seperti bidan yaitu terkait tuntutan tugas ideal dan keterpaksaan dan desakan ekonomi dan financial.

\section{Analisis Kerangka Kerja Koalisi Advokasi}

Weible \& Sabatier, melakukan tinjauan berdasarkan kerangka kerja koalisi advokasi yang terdiri dari stable parameters, ekternal system eventis dan subsistem kebijakan. ${ }^{11}$

Terdapat beberapa parameter penting yang dianut masyarakat diantaranya adalah agama dan falsafah Negara. Nilai-nilai dan norma yang berlaku di masyarakat bersumber pada agama dan semua agama menekankan pentingnya ASI dan kesehatan. Sebagai contoh di agama Islam, Nabi Muhammad SAW telah menekankan pentingnya memberikan ASI sampai usia 2 tahun.

Terdapat beberapa parameter penting yang dianut masyarakat diantaranya adalah agama dan falsafah Negara. Nilai-nilai dan norma yang berlaku di masyarakat bersumber pada agama dan semua agama menekankan pentingnya ASI dan kesehatan. Sebagai contoh di agama Islam. Nabi Muhammad SAW telah menekankan pentingnya memberikan ASI sampai usia 2 tahun.

Falsafah bernegara Pancasila dan UUD 1945 juga tidak ada yang bertentangan dengan ASI ekslusif dan IMD, bahkan mendukung penuh. Pemberian ASI adalah tindakan yang sesuai dengan sila kedua Pancasila karena pemberian ASI sesuai dengan fitrah manusia. Pada intinya praktik pemberian ASI ekslusif tidak bertentangan dengan dasar-dasar bernegara dan bermasyarakat.

Dalam hal external system events, telah terjadi perubahan opini publik mengenai ASI ekslusif dan IMD. Hal ini terjadi antara lain karena pergeseran situasi kondisi sosiaol ekonomi yang berpengaruh terhadap 
semakin lebarnya gap tingkat pendidikan ibu dari golongan ekonomi tinggi dan rendah, meningkatnya jumlah perempuan bekerja, serta meningkatnya promosi consumers goods termasuk iklan produk susu formula. Saat ini golongan ekonomi tinggi semakin mampu untuk mendapat pendidikan sementara golongan rendah semakin tidak mampu untuk bersekolah. Perbedaan ini juga berpengaruh terhadap penerimaan ibu mengenai ASI ekslusif dan IMD. Ibu yang berpendidikan tinggi lebih baik penerimaannya terhadap ASI ekslusif dan IMD serta lebih berupaya untuk bias mempraktikannya. ${ }^{6}$

Studi Huffman \& Lamphere menunjukkan pentingnya peran ASI ekslusif di Negara berkembang di bandingkan Negara maju. ${ }^{29}$ Di Negara maju ketika hygiene dan sanitasi sudah baik, peran ASI ekslusif hampir dapat digantikan oleh susu formula karena susu formula sudah dapat disajikan dalam porsi dan kebersihan yang terjaga dan mendekati kualitas ASI. Sementara di Negara berkembang penyapihan dan pemberian makanan pengganti ASI menyebabkan anak menjadi mudah sakit dan status gizi kurang.

Keberhasilan ASI ekslusif dan IMD tidak pernah terjadi bila iklan susu formula masih sangat marak di lakukan. Studi menunjukkan bukti yang jelas bahwa pemasaran susu formula mempengaruhi tenaga kesehatan dan ibu untuk memberikan susu formula kepada bayi. ${ }^{30}$ Tanpa adanya sanksi dan upaya yang optimal dari pemerintah bagi pemasaran susu formula sangat sulit target ASI ekslusif dan IMD bisa di capai.

Saat ini sudah sangat umum apabila masalah kesehatan di jadikan ajang promosi dalam pemilu. Kesempatan ini sangat baik untuk membangun komitmen dari penentu kebijakan untuk mengutamakan pemberian ASI ekslusif dan IMD. Apabila ini semakin banyak dilakukan kemungkinan aadanya komitmen di tingkat pemerintahan terhadap kebijakan ASI ekslusif dan IMD akan lebih mudah terlaksana.

Dalam subsistem kebijakan, kendati di kalangan kesehatan pentingnya ASI ekslusif dan IMD tidak diragukan. ASI ekslusif dan IMD belum terlalu di perhitungkan. Selama ini diskusi antar koalisi yang penting tidak terdokumentasi dengan baik. Seperti telah di bahas sebelumnya pengambilan keputusan dan penentuan kebijakan berlangsung tidak transparan dan tidak terdokumentasi dengan baik. Demikian juga dengan pengalokasian dana dan penunjukan tugas dan kewenangan belum jelas tindak lanjutnya. Selama ini tidak ada kejelasan penerapan sanksi, insentif, monitoring dan evaluasi dari kebijakan mengenai ASI ekslusif.

\section{SIMPULAN}

Studi ini menemukan bahwa pemberian ASI ekslusif di RS Bersalin Budi Kemuliaan masih rendah dan fasilitas IMD belum optimal sehingga tidak dapat dilakukan secara sempurna. Analisis kebijakan menunjukan bahwa kebijakan mengenai ASI ekslusif belum lengkap dan belum komprehensif. Juga ditemukan bahwa IMD belum secara eksplisit dimasukkan dalam kebijakan. Peraturanperaturan yang di bahas dalam analisis ini masih terlepas dari konteksnya baik konteks individu, keluarga, masyarakat, maupun institusi. Dari segi proses, penyusunan kebijakan terlihat kurang transparan, lambat dan kurang 
partisipatoris. Belum ada peme-taan pemeran (aktor) yang jelas teru-tama pengaturan kewenangan dan tanggung jawab yang bersifat lintas sektoral dan lintas level. Perlu dilakukan perbaharuan kebijakan yang ada agar relevan dari segi konten, konteks, proses dan aktor dan kebijakan mengenai ASI ekslusif dan harus memasukan unsur IMD. Perkembangan dan dinamika kebijakan ASI ekslusif perlu terus menerus di cermati agar dapat dilakukan pengawalan terhadap kebijakan tersebut sehingga dapat diimplementasikan secara efektif.

\section{Etik dan Ucapan Terimakasih}

Penulis mengucapkan terimakasih kepada pimpinan dan staf $\mathrm{RS}$ Bersalin Budi Kemuliaan yang telah mengizinkan dan membantu terlaknasanya studi ini. Kesediaan informan studi ini adalah sukarela, mempertimbangkan aspek etika terkait dan tidak melaporkan identitas personal secara individu.

\section{DAFTAR RUJUKAN}

1. Edmond KM, Zandoh C, Quigley MA. Amenga Etego S, Owusu-Agyei S. Kirkwood BR. Delayed breastfeeding initiation increases risk of neonatal mortality. J Pediatrics 2006;117(3):e380-386.

2. Besar DS. Metode amenore laktasi. Makalah dalam seminar telaah mutakhir tentang ASI, 2001.

3. Badan Pusat Statistik, BKKBN, Departemen Kesehatan. Survey Demografi dan Kesehatan Indonesia 2002-2003. Jakarta: Badan Pusat Statistik, 2003.

4. Badan pusat Statistik, BKKBN, departemen Kesehatan. Survei Demografi dan Kesehatan Indonesia 2006-2007. Jakarta: Badan Pusat Statistik, 2007.

5. Fikawati S, Syafiq A. Hubungan antara Immediate Breastfeeding dan ASI ekslusif 4 bulan. Jurnal Kedokteran Trisakti 2003;22(2):47-55.

6. Fikawati S, Syafiq A. Praktik pemberian ASI ekslusif, penyebab-penyebab keberhasilan dan kegagalannya. Jurnal Kesmas Nasional 2009;4(3):120-131.

7. Linghard $R$. Alade $M$. Delivery self attachment. The lancet 1990;336:1105-07.

8. Vaidya K.Sharma A, Dhungel S. Effect of early mother-baby close contact. Nepal Medical College 2005;7(2):138-140.

9. Departemen kesehatan Republik Indonesia Direktorat Jenderal Bina Kesehatan Masyarakat. Buku Acuan Pelatihan Klinik Asuhan Persalinan Nprmal Asuhan Esensial. Pencegahan dan Penanggulangan Segera Komplikasi Persalinan dan Bayi Baru Lahir, Jakarta: Depkes RI, 2008.

10. Walt G. Gibson L.Reforming the health sector in developing countries: The central role of policy analysis. J Health Policy Plann 1994;9(4):353-370.

11. Fischer F, Miller GJ, Sidney MS. Handbook of Public PolicyAnalysis;Theory, Politics and Methods. Florida:CRC Press, 2007.

12. Palmer GR. Short SD. Health Care and Public Policy, an Australian Analysis ed.Melbourne; Mac Milan Education Australia, 1998.

13. World Health Organization. The Optimal Durationof Exclusive Breastfeeding, Report of an Expert Consultation. Geneva, Switzerland: World Health Organization, 2002.

14. Kramer MS, Tongguo, Platt RW, Shapiro S, Collet JP, Chalmers B,et al. Breastfeeding and infant growth: Biology or bias J. Pediatrics 2002;110(2):343-7.

15. Syafiq A. Fikawati S. Mercy Corps Healthy Start Baseline Survey North Jakarta,Indonesia, Final Report.Depok: Center For Health Research University of Indonesia, 2007.

16. Anonim, Turun, jumlah bayi yang dapat ASI ekslusif. Gizi Net (Internet). 2009 (diakses 13 Desember 2009). Tersedia di;http;//www.gizi.net/cgibin/berita/fullnews.cgi?newsid1173324133.3 9743.

17. Putra A. Analisis Praktek Bidan Dalam Pelayanan Bagi Ibu Bersalin dan Bayi BAru LAhir 0-7 Hari (Minggu Pertama) Pasca Persalinan Di Kecamatan Lembah Gumanti 
Kabupaten Solok Tahun 2007 (Studi Kasus Di Wilayah Kerja Puskesmas Alahan Panjang). Tesis, Fakultas Kesehatan Masyarakat, Universitas Indonesia, Indonesia, 2007.

18. Roesli U. Inisiasi Menyusu Dini dan ASI ekslusif. Makalah dalam Presentasi Pada Bidan dan Perawat di Rumah Sakit Cibinong. Cibinong: RS Cibinong, 2008.

19. Depkes. Peraturam Menteri Kesehatan No 240/MENKES/PER/V/1985 tentang

Pengganti ASI. Jakarta: Depkes, 1985.

20. Depkes. Keputusan Menteri Kesehatan RI No.237/Menkes/SK/IV/1997 tentang Pemasaran Pengganti ASI. Jakarta: Depkes, 1997.

21. Presiden RI. Peraturan Pemerintah No.69 tahun 1999 tentang Label dan Iklan Pangan. Jakarta: Sekretariat Negara, 1999.

22. Depkes. Kepmenkes RI No. 450/Menkes/SK/IV/2004 tentang Pemberian ASI secara Ekslusif pada bayi di Indonesia. Jakarta: Depkes, 2004.

23. Kementerian Ko-Kesra RI. Rekapitulasi Pengharmonisan Rancangan Peraturan Pemerintah (RPP) [Internet].2009 [ diakses 13 Desember 2009] Tersedia di; http;//djpp.depkumham.go.id/perkembanganharmonisasi-rpp-tahun-2009.html

24. Bappenas. Pidato Kenegaraan Presiden RI 17 Agustus 2009 [internet].2009[diakses 13 Desember 2009]. Tersedia di; http;//www.bappenas.go.id/node/127/2037/pi dato-presiden-dan-lampiran-pidato-tahun2009. Jakarta: Bappenas, 2009.
25. Undang-Undang Republik Indonesia Tentang Ketenaga Kerjaan No.13/2003 Pasal 81

26. Napza Indonesia. ICDPR: Proses Pembuatan UU Narkotika Sangat Tidak Partisipatif. Napza Indonesia [internet]. 2009 [diakses 13 Desember 2009]. Tersedia di;http://napzaindonesia.com/icdpr-prosespembuatan-uu-narkotika-sangat-tidakpartisiparif.html.

27. Tempo Interaktif. Susu Formula menghambat produksi ASI. Tempo Interaktif [Internet].2009[diakses 13 Desember 2009] Tersedia di; http//www.tempointeraktif.com/hg/nasional/2 006/11/30/brk.2006/11/30/brk.2006113088704.id.html.http://www.tempointeraktif.com /hg/nasional/2006/11/30/brk.2006113088704.id.html.2009

28. Anonim. Pembahasan pengaturan pemasaran susu formula [internet].2009 [diakses 13 Desember 2009]. Tersedia di; http;//www.kapan lagi.com/h/0000064064 print.html.

29. Huffman S. Lamphere B. Breastfeeding Performance and Child Survival Strategies for Research Cambridge:Cambridge University Press, 1984.

30. UNICEF, WHO, Baby-Friendly Hospital Initiative: Revised, Updated and Expanded for Integrated Care,New York: UNICEF/WHO, 2006. 